This article was published in Journal of Eastern African Studies 5/4 (2011). Below is the manuscript form of the final, peer-reviewed accepted version. For the typeset published version, please see http://www.tandfonline.com/doi/full/10.1080/17531055.2011.642539.

First co-author's present contact information:

Dr. Jörg Haustein, SOAS University of London joerg.haustein@soas.ac.uk

\title{
EPRDF's Revolutionary Democracy and Religious Plurality: Islam and Christianity in post-Derg Ethiopia
}

\author{
Jörg Haustein* and Terje Østebø**i \\ * Department of History of Religions and Mission Studies, Faculty of Theology, \\ University of Heidelberg, Heidelberg, Germany \\ ** Center for African Studies \& Department of Religion, University of Florida, \\ Gainesville, USA
}

\begin{abstract}
In 1991 the Ethiopian Peoples' Revolutionary Democratic Front (EPRDF) introduced policies aimed at recognizing the country's long-standing religious diversity, providing a public arena for religious groups, and maintaining a sharp division between religion and the state. This further eroded the traditionally dominant position of the Ethiopian Orthodox Church, strengthened Protestant Christian and Muslim communities, and created a more flux and competitive configuration among the religious communities. Seeking to maintain its political power, the EPRDF has at the same time made efforts to monitor and control the different religious communities. Therefore, the last twenty years have been marked by uneven developments, in which the government's accommodating attitudes have been interlaced with efforts to curtail the influence of the religious communities. This paper surveys the intersection and reciprocal influences between EPRDF policies and religious communities over the last twenty years, and discusses how Muslims and Christians (Orthodox and Protestant) have negotiated their roles in relation to politics and public life. These developments have, the paper argues, led to the emergence of divergent and competing narratives, reconfiguring selfunderstanding, political aspirations and views of the religious other. The EPRDF ideology of 'revolutionary democracy' has, in this sense, enabled religion to surface as a force for social mobilisation and as a point of reference for attempting to define nationhood in Ethiopia.
\end{abstract}

Keywords: Ethiopia; Islam; Christianity; Ethiopian Politics 
The 1991 political transition announced a new era for Ethiopia's Christian and Muslim communities. The Ethiopian Peoples' Democratic Front (EPRDF) issued new policies and introduced a legal framework aimed at recognizing the country's inbuilt diversity. The lifting of earlier restrictions on religious expressions made religion more visible in public, and led to a sharp increase in religious activities and religious diversity, in effect strengthening Protestant and Muslim communities and counterbalancing the traditional hegemonic position of the Ethiopian Orthodox Church (EOC).

This paper surveys the intersection of EPRDF's policies and the reconfiguration of the religious landscape in contemporary Ethiopia. By assessing the legal and political parameters for religions in post-Derg Ethiopia, the paper demonstrates how the ruling party provided a government-independent framework for religious plurality, yet at the same time sought to control and monitor religious activities. The paper also explores the strategies adopted by Muslims and Christians (Orthodox and Protestant) in maneuvering under such circumstances, and points to how the increasing religious activities and diversity have intensified debates about religion and politics - and about being Ethiopian.

\section{Political and legal parameters for religion in Ethiopia}

The religious policies of the present Ethiopian government are remarkably different from any of the previous ones with regard to the measure of religious freedom they provide. During the Imperial Government of Haile Selassie modernizing impulses had already led to tentative provisions of religious liberty, like freedom of worship, recognition of shari' $a$ courts, and provisions for the registration of religious associations, but these were not put into practice, and the EOC retained its monopoly and political power until the revolution of $1974 .{ }^{\text {ii }}$

In this revolution, religious freedom became one of the passionately voiced demands. These were initially realized to some degree, for example with the acceptance of Islamic holidays as public holidays, the permission to establish the Ethiopian Islamic Affairs Supreme Council (EIASC), and with Pentecostals allowed to congregate in public. However, the revolutionary rulers' turn to scientific socialism soon brought about polemic campaigns against religion as well as the violent co-optation of the old religious center of the Ethiopian highland state, the EOC. This process, culminating in the 
deposition, murder, and replacement of Patriarch Theophilos in 1976, signaled the end of whatever religious freedom the revolution had brought. In the following years all Pentecostal and many Protestant churches were closed, and Muslims in Eastern Ethiopia, accused of siding with the Somalis during the Ogaden-war, were hit hard by the Derg. After the political consolidation of Mengistu's regime and as a result of the humanitarian crisis of the 1980s, some faith communities were given a measure of religious freedom in exchange for their participation in the political system. The constitution draft commission of 1986, for example, not only included the Orthodox patriarch, but also leaders from the Lutheran Ethiopian Evangelical Church Mekane Yesus (EECMY), the Catholic Church and the EIASC. Members from these religious communities were also elected to the Shengo. ${ }^{\text {iii }}$

When the EPRDF ousted the Derg in 1991, religious liberties were quickly introduced at an unprecedented scale. This had little to do with ideological differences to the Derg regime, ${ }^{\text {iv }}$ but more with a different political strategy of appropriating religion. On the one hand, their reliance on rural peasants for revolting against the Derg had taught the new rulers to respect the deep-seated religious sensibilities of most Ethiopians, ${ }^{\mathrm{v}}$ and on the other hand the religious plurality of Ethiopia dovetailed nicely with the new governing philosophy of ethno-regional federalism, as is stated in Article 13 of the new constitution: "[t]he national emblem on the flag shall reflect the hope of the Nations, Nationalities, Peoples as well as religious communities to live together in equality and unity." Accordingly, article 11 marks a clear separation of religion and state, rules out a state religion and provides the assurance of no government interference in religious matters and vice versa. Article 27 warrants freedom of religion, belief, and opinion, which includes the right of believers to "establish institutions of religious education and administration in order to propagate and organize their religion." Furthermore, the constitution opens up the possibility for the recognition of religious marriage ceremonies and of religious courts relating to personal and family issues (arts. 34, 78). The new government also brought an end to restrictions on the hajj, suspended the ban on the import of religious literature and eased the restrictions on the construction of mosques and religious schools. ${ }^{\text {vi }}$ The Imperial regulations regarding the registration of religious communities now were put into practice, resulting in the first official recognition of many 
Protestant and especially Pentecostal churches. These churches also succeeded in reclaiming property that was dispossessed by the Derg and were given land grants for burial sites and church buildings.

However, the laws pertaining to the registration of religious organizations with the government may also be seen to contradict the constitutional provisions of religious freedom and equality. The EOC is still exempt from registration by the Civil Code of 1960, whereas for all others registration is a legal mandate. The Penal Code of 1957 and its replacement, the 2004 Criminal code, contain punishments for participating in, or leading the activities of an unregistered association. ${ }^{\text {vii }}$ Furthermore, the Legal Notice of 1966, which still governs the process of registration, states that an application may be denied if the purposes of the association are found to be "unlawful or immoral," or "against national unity and interests." viii However, so far there is no indication that applications have been denied for anything but formal reasons.

Another area in which the current legislation may lead to government interference with religious activities pertains to land use. All land is owned by the State according to article 40 of the constitution, but the relevant legislation governing the lease of urban and rural land does not address issues related to religious bodies, such as how to prioritize applications, whether to lease land to very small religious communities, or how churches, mosques, or cemeteries should be placed within the infrastructure of a settlement. All of these decisions are delegated to local governments where the influence of a religious majority may guide decisions.

Thus, comparing the present situation of religious politics with previous Ethiopian governments, there has been an evident improvement with regard to religious liberty and equality. The Ethiopian constitution promotes religious plurality, which is supported by the separation of religion and state, the promulgation of religious freedom, as well as provisions for religious courts and institutions of religious propagation. However, the legal framework for registrations and land lease gives considerable power to the executive, which corresponds with the EPRDF's interest to closely monitor religious communities, being conscious about the potential power they represent. This concern has led to government interventions contradicting the legal provisions for religious freedom as will be shown below. 


\section{The impact of EPRDF politics on religion}

The combination of increasing religious plurality and executive influence on religions has played out quite differently for the Orthodox, Protestant and Muslim communities, producing dissimilar trajectories in the renegotiation of public space, political power and religious freedom.

\section{Plurality and fragmentation}

The current religious composition of Ethiopia is characterized by the 2007 census as follows: Ethiopian Orthodox Christians hold the majority with 43.5 percent, followed by Islam (34.0 percent), and Protestant Christianity (18.5 percent). ${ }^{\text {ix }}$ There is a considerable regional variation with regard to religious predominance. Muslims are dominant in the Afar Region (95.3 percent), Dire Dawa (70.8 percent), Harar (69.0 percent) and the Somali Region (98.4 percent), as well as in the special enumeration areas (92.5 percent). Orthodox Christianity predominates in Addis Ababa (74.7 percent), Amhara Region (82.5 percent), and Tigray Region (95.6 percent), whereas Gambella and Southern Nations, Nationalities and Peoples' Region are largely Protestant (71.1 and 55.5 percent, respectively). Even religiously heterogeneous regions, such as Oromiya are made up in part of fairly homogenous zones. Furthermore, in all regions, religious majorities are amplified in rural areas, which shows that religious plurality in Ethiopia is first of all an urban phenomenon. The religious distribution in Ethiopia therefore largely correlates with regional and ethnic boundaries, making it compatible with the EPRDF's political philosophy of ethno-regional federalism.

One of the most significant demographic shifts that the census indicates is the rise of Protestantism, which grew from 5.5 percent of the overall population in $1984,{ }^{\mathrm{x}}$ to 10.2 percent in $1994,{ }^{\mathrm{xi}}$ to the already mentioned 18.5 percent in 2007 . Most of this increase has come at the cost of the EOC, whose share declined from 54.0 percent in 1984 to 50.6 percent in 1994, and 43.5 percent in 2007.

The increase of Protestantism is accompanied by a significant and still growing influence of Pentecostal and Charismatic beliefs and practices. Ethiopian Pentecostalism began to emerge in the 1960 s, but was marginalized and for the most part actively 
repressed during Haile Selassie's government and the Derg. ${ }^{\text {xii }}$ However, with the policies of religious freedom inaugurated by the EPRDF, Pentecostal churches have become a highly visible part of Ethiopian Protestantism, especially since their theology and practices have spread to mainstream Protestant churches as well, where speaking in tongues, ecstatic praise, prophesy, exorcisms, and healing prayers now are common phenomena. All of the large mainline Protestant denominations have accommodated Pentecostal beliefs and practices in their doctrinal statements and regulations, ${ }^{\text {xii }}$ and the conflation of Pentecostalism and Protestantism has an organizational correlate in the Evangelical Churches' Fellowship of Ethiopia (ECFE), which comprises Pentecostals and mainline Protestants at once. In public discourse, all Protestants are labeled "Pente", which at first was a polemic practice by the Derg to stigmatize all Protestants, ${ }^{\text {xiv }}$ but now has become a self-designation for many of them as well.

Due to their previous repression under the Derg, most Protestants were in no need of a political realignment, perhaps with the exception of the EECMY, which after the murder of its general secretary Gudina Tumsa - an outspoken critic of the Derg - had taken a more compliant stance. Therefore, when the EPRDF came to power, the church's president, Francis Stephanos did not run for reelection due to his previous involvement in the Shengo. ${ }^{\mathrm{xv}}$ There was, however, no further realignment or immediate political conflict in the church regarding this issue.

In general, Protestant churches have benefited greatly from the changes in religious policy. All of them immediately re-emerged in public in 1991 and successfully reclaimed their formerly dispossessed property. Despite occasional local difficulties, it became much easier for Protestants to secure land for church construction and for burial grounds, which had been a notoriously difficult issue before. This is especially significant in areas to which they previously had hardly any access to. In the largely Orthodox town of Bahir Dar, for example, Protestants erected tall churches on land granted to them by the government, which visibly compete with Orthodox buildings. This increased public visibility of Protestantism in Orthodox areas has led to a number of clashes and riots, during which government forces have usually protected the Protestant gatherings. ${ }^{\text {xvi }}$

The registration mandate was generally welcomed by Protestant churches, since for many of them - especially those not operating under the umbrella of foreign missions - 
this was the first time they could obtain official recognition. Moreover, the organizational requirements for registration and the legal recognition it awards are largely compatible with Protestant church models and their tendencies to grow via fragmentation. A list of registered associations obtained from the Ministry of Justice in 2004 indicates the mushrooming of Protestant associations. Of the 291 religious denominations, churches, and ministries in this list, the absolute majority belongs to the Protestant fold and many of them are Pentecostal or Charismatic.

The separation of church and state also has led to a noticeable increase of Protestants and Pentecostals in government positions, in effect weakening the former political influence of the EOC. The most prominent Protestant government official is the current foreign minister, Haile Mariam Desalegne, who belongs to the Hawariyat Church, a large Pentecostal denomination, which however, is ostracized by all other Christians since it does not accept the dogma of the trinity.

So far, this new public space for Protestants has not been limited by the EPRDF in any significant way, but its policies nevertheless affect the churches' internal dynamics. One area for this is the ethnicization of politics. The issue has had an especially significant impact on the EECMY, which due to its mission history in Western Ethiopia has a strong Oromo base. ${ }^{\text {xvii }}$ When the Oromo Liberation Front (OLF) fell out with the government in 1992 and resorted to armed struggle, the church tried to stay clear of political involvement with the OLF. At the same time, however, it resumed relations with the Berlin Mission, which is a vocal supporter of the OLF and actively aids its relief and development wing, the Oromo Relief Association (ORA). While this issue of whether and how to speak out on behalf of Oromo rights continues to be a politically difficult balancing act, the question of ethnicity erupted within the church over the use of the Oromo language in church services in Addis Ababa. A large number of Addis Ababa churches resisting the introduction of Oromo language services left the EECMY, registering under the name of Addis Ababa and Surrounding Mekane Yesus Church. ${ }^{\text {xviii }}$ This spurred court cases regarding the use of the name and the involved property. After many negotiation attempts, the parties were officially reconciled in February 2010. ${ }^{\text {xix }}$

In these kinds of church splits, which have also occurred in many of the large Protestant churches over different issues, the government functions as a regulatory 
instance through its policies, especially the requirement of registration. The need to conform to certain standards with regard to uniqueness of name, organizational structures or financial oversight, imposes limitations on church fragmentation and simultaneously defines areas of church conflict. In some cases, like in the EECMY split, the government may even assume an active role in conflict resolution and the celebration thereof. ${ }^{\mathrm{xx}}$ However, outside of these regulatory confinements, occasional executive issues of land allotment, and similar problems, there are no indications of direct government influence in Protestant churches or political pressure on them.

\section{Renegotiating central powers}

The violent co-optation of the EOC during the Derg, the expropriation of its property, and ideological campaigns against religion had curtailed the political power and independence of the church. Therefore, when the EPRDF came to power, the EOC leadership once again was strongly impacted, most evident in the replacement of the patriarch in 1991. This was a controversial process, which was driven by a conflation of government and church politics.

An internal observer's report of the Tenth Parish Council General Assembly in October of 1991 reveals a conflicting and deeply divided church. ${ }^{\text {xi }}$ Patriarch Merkorios is noted to have "verbally resigned in August due to illness and the pressure of work." A number of clergy and lay people apparently partook in public demonstrations, partially instigated by the General Secretary of the Church, who was then removed and replaced with a government appointment. This was a clear violation of the EPRDF's policy of non-interference in religious matters, but the underlying motives are unclear. While public demonstrations certainly were not acceptable to the new government, it is questionable whether the EPRDF was interested and capable of replacing the church's leadership only a few months after taking over Addis Ababa. Moreover, the absence of dissenting voices in the internal report may indicate that the faction who sought to replace the patriarch had already taken over within the church.

Political tensions resulting from the Derg's deposition and replacement of Patriarch Theophilos now played out in reverse. The Holy Synod replaced its chairman in February 1992 and in June elected Abuna Paulos as the new patriarch, enthroned on 12 July 1992. 
Paulos was a protégé and political ally of the former Patriarch Theophilos, for whom he had worked as a contact person to the World Council of Churches (WCC), becoming Bishop for Ecumenical Affairs in 1975. When Theophilos was deposed and murdered by the Derg in 1976, Paulos was arrested as well, and held in prison until 1983. With the assistance of the WCC, he managed to leave Ethiopia and completed his $\mathrm{PhD}$ at Princeton University in 1988. While in the USA he reportedly clashed with his long-time acquaintance $A b b a$ Yesehaq, the Archbishop of the Western Hemisphere Diocese, which is the umbrella diocese for Orthodox churches in Europe and America. Yesehaq seems to have arranged himself with the Derg-aligned hierarchies and defended the Derg's appointment of Theophilos' successor. ${ }^{x x i i}$ Paulos on the other hand, probably collected Ethiopians opposing the Derg in his New York church, and did not accept Yesehaq's authority. He therefore, was the ideal candidate to reverse the politics of the church: standing in continuity with the uncanonically replaced Theophilos, ${ }^{x i i i}$ he was an opposition figure in exile and was well established internationally.

Not surprisingly, it was Yesehaq who initiated and led the secession of the Western Hemisphere Diocese, when Patriarch Merkorios left Ethiopia for Kenya in 1992 and claimed that he had not abdicated willfully. The exiled synod attracted Ethiopian clergy who were opposed to Paulos' election and in 1997 Patriarch Merkorios relocated to the USA. The split proliferated to a number of Western cities, and in 2007 Merkorios anointed thirteen bishops for the exile synod, which led to both factions excommunicating each other. ${ }^{\text {xxiv }}$ The exile synod claims that the election of Paulos, who is a Tigre like most high-ranking government officials, was an orchestrated coup by the EPRDF. However, other than the appointment of a new general secretary, there are no clear indications of direct government interventions, whereas it is clear that members of the church's hierarchy interested in reversing the previous political alignment effectively drove this process and used or welcomed government involvement in order to attain their goals.

This conflation of church and EPRDF politics and the central public role of Ethiopian Orthodoxy contributed to the politicization of the EOC. Paulos' opponents emphasize his ethnicity to paint him as a puppet of the EPRDF, and negative perceptions of the EPRDF usually translate into opposition toward Paulos as well. ${ }^{x x v}$ In the bloody 
aftermath of the 2005 elections, many hoped for a critical statement from the church and interpreted its call for peace as support for the EPRDF. This in turn led to the heckling of Paulos during the Meskel celebrations in September of the same year. ${ }^{\text {xxvi }}$ The suppression of government critical prophesying monks or bahitawis has played into this narrative, especially when in 1997 bahitawi Fekade Sellasie Tesfaye was shot and killed inside the St. Stephanos Church in Addis Ababa by one of Paulos guards. ${ }^{x x v i i}$

\section{Restricting public space}

As seen from the statistics above, Islam has not experienced such a dramatic increase in numbers as Protestantism. The most significant change during EPRDF rule was that Muslims have become far more visible within Ethiopian public space. Generally, the increasing visibility of Islam is evident by the mushrooming of mosques throughout the country, by the increase of "Muslim clothing", such as hijab among women, and skullcaps and white robes among males, as well as by the performance of religious ritual in public.

More specifically, the new political climate in the early 1990s contributed to the institutionalization of Islam. A first important step was the de jure establishment of the EIASC in 1991, and the restructuring and election of a new leadership in October 1992. ${ }^{\text {xxviii }}$ Other crucial organizations were the Ethiopian Muslim Youth Association and the Da'wa \& Knowledge Association, both established in 1992. These organizations were heavily focused on "reviving Islam" and played decisive roles in making religious literature available, in the construction of mosques and in supporting various forms of $d a$ 'wa. ${ }^{\text {xix }}$ The early 1990s also saw the emergence of a number of Islamic magazines and various publishing houses - engaged in importing and translating religious texts from Arabic as well as publishing works by indigenous Muslim writers. ${ }^{\mathrm{xx}}$ Islamic education became more structured in the form of madrasas with teaching structured through classrooms, defined grade-levels, and syllabi. While such madrasas in various sizes appeared all over the country, a major one was the Awaliyah School \& Mission Centre in Addis Ababa, which saw the adding of new departments and faculty during the 1990s. The school had been supported by the Saudi-based World Muslim League (MWL) since 
1966, and in 1993, the formal ownership of the school was transferred to International Islamic Relief Organization, a branch of MWL. ${ }^{\text {xxi }}$

While the developments leading to a more organized and visible Muslim community went relatively unchecked in the first half of the 1990s, the years 1995 and 1996 became a watershed for organized Muslim activities. With reference to the growth in the number of mosques all over the country and the increasing number of Muslims holding governmental and public positions, Christians were becoming gradually worried over Islam's increasingly visible role in public space. The government was similarly showing signs of concern over increased religious activism, which they perceived to be a trend of politicization of Islam. This fear was amplified by a demonstration in Addis Ababa in November 1994, when Muslims demanded that the shari'a should be included as one of the bases for the national constitution. When worshippers at the al-Anwar mosque in Addis Ababa clashed with the police on 21 February 1995, leaving nine people killed and over one hundred wounded, the government used this as an opportunity to crack down on unwanted developments within the Muslim community. ${ }^{\text {xxxii }}$ In the following days, hundreds of Muslims were imprisoned, suspected of involvement, and on the 22 February, armed police surrounded the offices of the Ethiopian Muslim Youth Association. All those present were arrested, and the offices were closed. The situation worsened after the failed assassination attempt against the Egyptian president Hosni Mubarak during his visit to Addis Ababa on June 26 the same year. Five of the attackers were killed on the spot, and it was later learned that the Egyptian organization Jama'a alIslamiyya, allegedly with the assistance of Sudan, was responsible for the assassination attempt. $^{\text {xxiii }}$ The incident led to continued arrests, and to the extradition of Egyptian and Sudanese nationals. In addition, the bomb-attacks by the Somali al-Itihad al-Islamiyya on Ethiopian soil from May 1995 to April 1996 - and Ethiopia's retaliation - further fuelled tensions.

The ruling party's reactions deprived Muslims of much of the freedoms they had acquired since 1991, and with the closure of Islamic organizations, it left the EIASC to emerge as the sole actor claiming to represent the Muslim population as a whole. The council's vast apparatus and its close links with the government have effectively enabled the latter to monitor and control developments within the Muslim community. The 
council has on its side proved to be a loyal instrument in curbing unwanted movements in particular the Salafi movement, or the Wahhabis, as it is referred to locally. In January 2004, the EIASC voted to remove all executive members of the council, replacing them with staunch anti-Salafis. Interesting to note is that the voting session was attended by a representative from the Ministry of Foreign Affairs. The hegemonic position of the EIASC has consequently impinged on the possibilities of forming alternative organizations, which has contributed to a situation in which Islam in Ethiopia is highly informal and de-institutionalized. An effect of this was, however, that the mosque became increasingly important, to a certain degree representing closed space for the authorities and consequently encumbering their possibility to monitor the movements of the Muslim community.

The terror-attacks on $9 / 11$ and increased geopolitical tensions in the region spurred increased concern from the ruling party, and Ethiopian Muslims were publicly accused of aspiring to political power based on radical religious ideas. ${ }^{\text {xxiv }}$ The EPRDF's fear of political Islam was exacerbated by the increasing strength of Islamist insurgents in Somalia, and the political takeover by the United Islamic Courts (UIC) in June 2006 sparked concern over its potential effects on Ethiopia's Muslim population. ${ }^{\mathrm{xxx}}$ The Ethiopian response came in late December 2006, when its forces crossed the border, swiftly ousting the weak, yet overconfident UIC from power. The military did not manage, however, to defeat the violent insurgent movement al-Shabab, which filled the vacuum left by the UIC and gradually grew in strength. In January 2009 the Ethiopian forces vacated Somalia, leaving it to the African Union forces (AMISOM) to deal with the Islamist insurgency. The EPRDF has, however, continued to meddle in Somalia by supporting political factions, like the Sufi-oriented Ahl al-Sunna wal Jama'a which it considers as representatives of a more "home-grown" tolerant and peaceful Islam - in contrast with Salafi actors perceived as representing a "foreign" militant Islam.

In convergence with this, the ruling party undertook several measures further restricting the public space of Muslims in Ethiopia. In May and November 2007, the Ministry of Education issued drafts for a law addressing the question of religious expressions in public schools. The constitutional tension between freedom of religious expression (Art. 27) and the mandate to keep education free from religious influence 
(Art. 90) ${ }^{\text {xxxi }}$ came to bear in the proposition to restrict the use of hijab and niqab in public schools, as well as the prohibition of congregational prayer within school premises. ${ }^{\text {xxvii }}$ Moreover, realizing that it was unable to monitor the activities within the growing number of mosques, the EPRDF issued, through the EIASC, in 2009 a registration-form to the country's mosques, ordering them to submit information on how they were run, on the sources for income and whether the mosque was linked to any outside donors. ${ }^{\text {xxviii }}$ On 23 February 2009 the government issued a ban on all Muslim religious activities which had not been approved on beforehand by the EIASC. ${ }^{\text {xxix }}$ There were also unconfirmed reports saying that the security apparatus had issued a list of nearly 100 Muslims to be arrested. ${ }^{\mathrm{xl}}$ No information on the background and reasons for this is available, but it seems that regional instability was an important factor.

\section{Politics, religion, and the negotiation of public space}

As seen so far, the combination of policies opening space for religious groups and executive actions imposing limits on the same, have had different impacts on the religious communities. With regard to the EOC, still the most visible and influential religious force in Ethiopia, there seems to be a certain conflation of EPRDF and church interests, which arguably is driven more by internal church politics than direct government intervention. The growing visibility of the Muslim community, on the other hand, has been subjected to increasing regulations and limitations, which are partially connected to the larger geopolitical developments in the region. Protestant churches, in turn, have hardly been the target of direct government intervention and have largely profited from the enforcement of religious plurality, while being structurally influenced by some of the government's policies.

These different trajectories have forced religious communities to apply certain strategies when moving in this space, which become apparent in the production of disparate narratives for the legitimization of religion in society, and in the demarcation of inter- and intra-religious boundaries being played out in the public once again.

\section{Political narratives}


The EOC has reacted to its loss of political power by more or less reiterating its importance for the integrity and identity of the Ethiopian nation-state with historical and cultural arguments. A book published by the patriarchate in 1997 states, for example: "Our culture, our strength, our freedom, our unity and our basic teachings are built on the foundation of our church. Therefore our church is the symbol of unity and freedom for Ethiopia as a whole and all Ethiopians, and the center of spiritual and social ministry." xli In a similar way, a history book published by the Mahibere Kidusan ${ }^{\text {xlii }}$ affirms the centrality of the EOC by outlining its contributions to the administrative and legal foundation of the country, its cultural and social life, the preservation of Ethiopia's heritage, and the promotion of tourism. ${ }^{\text {xlii }}$ Regretting the disintegration of this religiopolitical unity, the publication bemoans the "attacks of radical Islam and the spread of mosques" as an example for religious organizations which infringe the rights of the Ethiopian church and inflict attacks in the "name of freedom of religion and democracy."xliv Moreover, the incursion of "heretics", i.e. Protestants, is seen as a contributing factor to moral decay and social disintegration, since their insistence of salvation by grace and not by works has led to a decrease of "prayer, fasting, charity, self-control, solidarity, obedience, mutual respect, harmony, and similar goods." ${ }^{\mathrm{xlv}}$ These and similar statements, pointing to the dangers of religious liberty in contrast to the benefits of a close state-church alliance, affirm the political aspirations of the EOC and simultaneously outline its political strategy of compensating for the loss of power: By pointing to the historical and cultural heritage, the idea of an essentially Orthodox Ethiopia is upheld and defended against the perceived threats of Westernization and Islamic growth.

The political outlook of many Protestants, on the other hand, appears to be one of overt de-politicization, articulated in narratives of persecution and of personal faith in Jesus Christ as the solution to all ailments of society. Especially Pentecostals have learned to tell their history as a story of oppression, and in a somewhat triumphalist manner they portray the present religious liberties and the growth of Protestantism as rewards for previously endured sufferings. This legacy of persecution is also accompanied by a verdict on past regimes. In his Revival in Ethiopia the Pentecostal historian Bekele Woldekidan reflects on the legacy of Haile Selassie's government and 
tells how the emperor had been confronted with the gospel through various evangelists, but failed to stop the persecution of Pentecostals. ${ }^{\text {xlvi }}$ Bekele's verdict is clear: "His government tried to stop God's visitation, using the police force and judicial institutions. God in turn, used his own army and stopped that government." "xlvii Though the Derg is seen here as God's instrument to end imperial rule, it is soon judged in similar terms, since it too oppressed the revival movements. Such narratives of course contain an implicit political proclamation for present-day Ethiopia as well: the possibilities for Protestant evangelization define the character and survival prospects of Ethiopia's governments. This missionary zeal is connected to the assumption that only converted and sanctified believers will be able to abstain from corruption, improve the economy, and bring social change that lasts. The former prime minister of the Transitional Government, Tamrat Layne, became one of the most prominent proponents of this idea. In 1996 he fell out with Meles Zenawi, was imprisoned for twelve years on charges of fraud, and converted to Protestantism during this time. After his release he asserted that he would abstain from politics, since, in his opinion, Ethiopia could only be improved through people turning to Jesus Christ. ${ }^{\text {xlviii }}$ His testimony was given center stage in the biggest Pentecostal Church in Addis Ababa and received standing ovations. ${ }^{\text {xlix }}$

A notable exception to this overtly apolitical outlook may be the EECMY who holds a special political heritage in the memory of its former general secretary Gudina Tumsa. Especially during the transition period, the church attempted to revive Tumsa's political legacy and spoke out against different human rights violations. ${ }^{1}$ However, in recent years there has been less evidence of such involvement, which arguably has to do with the ethno-political conflict in the midst of the church and the growing influence of the Pentecostal political narrative.

While the developments in 1995/96 impinged on Muslims' access to public space, they did not diminish their engagement in politics. It needs to be noted, though, that Muslim views on politics has taken a different form than the often portrayed notion of seeking power based on Islamic political preferences. The Salafis have in general refrained from partaking in political debates, yet their view on politics - as forwarded by a range of Salafi informants - has largely been congruent with the official secular paradigm of the EPRDF, in which they argue that in a heterogeneous religious society 
like Ethiopia, religious freedom and equality for the different groups could only be secured under a secular government. . $^{\text {li }}$ The group most explicitly advocating involvement in politics is the so-called Intellectualist movement. Highly informal and devoid of any organizational structure, this rather elitist movement evolved around certain individuals advocating a set of ideas. It has been ideologically affiliated to the mainstream version of the Muslim Brotherhood, and has been actively disseminating the ideas of Hassan alBanna, and in particular those of Yusuf al-Qaradawi to the Muslim public. Initially surfacing on the campuses of Addis Ababa University and other institutions of higher learning in the early 1990s, it soon gained popularity among Muslim students. Outside the campuses, the movement was able to exert influence through public lectures and through regular contributions in Islamic magazines. Referring to discrimination found in Ethiopia's past, the Intellectualists have been much concerned with the legitimate place for Muslims in Ethiopian society, worked for equal representation of Christians and Muslims in public life, and argued for the creation of a secular political environment safeguarding and facilitating mutual respect between the religions and their peaceful coexistence.

The resurgence of the Takfir wal Hijralii in Jimma around 2005 pointed to a politicization of Islam. Taking an exclusivist position towards both Salafi and non-Salafi Muslims, the group has moreover assumed a radical position toward the Ethiopian state, seen among others by their refusal to hold ID cards and to pay taxes. When this was stated publicly in 2009, the EPRDF decided to send in the army, leading to violent clashes with the Takfiris and to the imprisonment of allegedly over 1500 men and women. ${ }^{\text {liii }}$ While the Takfiris probably see the establishment of an Islamist political order as desirable but unrealistic, they may opt for an isolationist strategy, detaching themselves from state and societal structures, seeking to carve out both symbolic and territorial space for the realization of their ideological preferences.

It seems that Muslims in the last decade have become increasingly critical of the EPRDF. From initially being supportive of the federalist system and subscribing to the secularist ideology of the state's non-involvement in religious affairs, the lack of democratization in general, the perceived bias towards the Christians, the intervention in Somalia, and the monitoring of the Muslim community are creating more negative 
attitudes towards the ruling party. A particularly burning issue is the ruling party's interference in the EIASC, which not only is seen as a breach of their constitutional rights, but also as depriving Muslims of independent representations and dividing them as a community.

\section{Demarcating intra-religious boundaries}

The rise of Protestant Christianity has led to considerable tensions between the two Christian blocks, which are deepened by their different political narratives. Moreover, Protestants often invoke a renewal rhetoric, which may turn into polemics, for example when they allege that the EOC has blurred the message of Christianity with its veneration of saints and elaborate ritual practices, and therefore must be brought back to the faith of the early church. ${ }^{\text {liv }}$ The resulting conflicts from these contrasting outlooks were not only manifest in public riots and condemnations but run right through many families, where they frequently take on the nature of inter-generational conflicts. ${ }^{\text {.v }}$ The Mahibere Kidusan explicitly addresses this point by targeting the educated youth, but their apologetic and unnuanced characterization of Protestants arguably contributes to widening the gap.

The increasing "Pentecostalization" of Protestantism has further hardened the fronts. The highly visible and audible nature of Pentecostal services puts them into direct competition with the EOC, and their strict prohibition of alcohol and dancing tends to divide social activities and family gatherings. In addition, Pentecostalism has helped to vitalize and contextualize mainstream Protestant churches, putting them in more direct competition with Orthodox nationalism.

Pentecostalism has also reached the EOC itself in the form of Orthodox Charismatic movements, some of which have come into conflict and broken away from the church. The most prominent example of this was the Ammanuel Fellowship (now Ammanuel United Church), which began as a prayer fellowship in Nazaret in 1991, left the church in 1995, and became increasingly Protestant in the following years until it finally joined the ECFE in 2004. Similar groups aiming to stay within the EOC, often congregate in secret, because the division between the largely Pentecostal Protestants and Orthodox Christians has left little room for hybrid Charismatic identities. 
Intra-religious tensions among Muslims have been much related to the growth of the Salafi movement. While the Salafis' attacks on pilgrimages to shrines, on saint veneration, and on other practices that are seen as 'contaminating the true faith' have provoked tensions and divisions among Muslims in Ethiopia, Salafism experienced, at the same time, internal fragmentation with the surfacing of what may be referred to as the so-called Ahl al-Sunna movement, which attracted followers largely from the young generation. This faction favoured a stricter interpretation of the Salafi tenets, in many instances leading to conflict with the senior Salafis. Pertinent issues that were addressed referred to morality and individual religiosity among the young generation in the 1990s, like agitating against alcohol, tobacco, khat, TV and pop-music, or prescribing certain codes of dress and personal appearance. The most radical wing of the Ahl al-Sunna came to be represented by the already mentioned Takfir wal Hijra grouping.

Intra-religious tensions in Ethiopia have also been related to the already mentioned Intellectualist movement and the Tabligh. The latter is probably the largest Islamic movement in Ethiopia, and seems to have arrived in Ethiopia in the early 1970s, by way of South African and Kenyan Tabligh missionaries, attracting followers among the Gurage community in Addis Ababa. Its activities remained limited under the Derg, resurfacing in 1991. Extensively focused on $d a^{\prime} w a$, Tabligh missionaries are sent out from its markaz (centre) in Kolfe area in Addis Ababa to various parts of the country. In accordance with Tabligh's principle of self-reliance, all the missionaries are supposed to take care of their own expenses, thus making the movement independent from any outside funding.

\section{Inter-religious relations}

Inter-religious relations in Ethiopia have deteriorated in recent decades, with an increase of skirmishes and violent clashes between Christians and Muslims. Many of the concrete conflicts between Christians and Muslims have been due to competition over public space in the literal sense - connected to construction of mosques or churches, as well as to celebrations of religious holidays. Clashes have mostly been of a local nature, the level of violence has been relatively low, and they do not reflect religiously coordinated efforts in augmenting tensions. Therefore, the inter-religious conflict and the high degree of 
violence that occurred around Jimma and in Beghi (Wollega) in 2006 came as a surprise to many. The conflict erupted in connection with the celebration of Timket in a village outside of Jimma, and gradually spread to the Beghi area. It resulted in casualties on both sides, churches were burned, and unconfirmed reports tell about Christians being forced to convert to Islam. ${ }^{\text {Ivi }}$ It is interesting to note that the group most actively involved in the conflict was said to "oppose paying tax to the government" and detaching themselves from the Christians and denouncing other Muslims - pointing in the direction of the

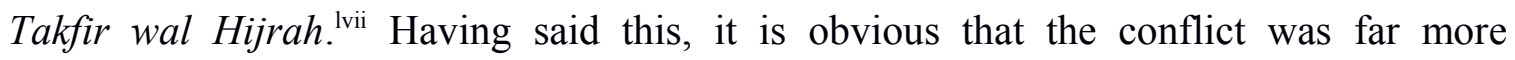
complex.

The current fragile situation involves a number of disparate actors, and remains related to the particular legacy of Christian-Muslim relations in Ethiopia feeding in to today's religious discourses both within the Christian and Muslim communities. Whereas the peaceful relationship between Christians and Muslims in Ethiopia has often been celebrated by both Ethiopians and foreign observers, this remains a simplification of a far more complex picture. Christians-Muslims relations on the micro-level have been of a seemingly harmonic character, yet relations on the macro-level have in contrast been more antagonistic, shaped by recurrent conflicts in the past. From the Christian side, emerging as victorious from the historic inter-religious conflicts, this enmity in turn laid the foundation for pejorative and hostile attitudes towards Islam, as well as to a religious fault-line in which Islam was perceived as a possible external threat. This has led to policies of alienation, marginalization, and subjugation, and the crucial point is that peaceful inter-religious coexistence to a large degree was made possible because of an asymmetric relationship between the two, in which Orthodox Christians controlled the main political institutions and defined the Muslims as second-class.

Since 1991, this pattern has been dramatically reversed. This rise in MuslimChristian tensions is arguably due to the new religious plurality abolishing this asymmetry. As constitutional changes and political reforms have highlighted Ethiopia's religious diversity, feelings of hope and expectations have emerged as well as discomfort and fear. Christians are in general seeing the rapid growth of mosques and Muslim representation in public life as a proof of a strategy of Islamization. As was shown above, Orthodox Christians view this as a sign of a disintegrating Ethiopian nation, bemoaning 
that the "contemporary religious equilibrium is collapsing very quickly,"lviii and becoming fearful of "Islamic fundamentalism" produced by local discourses, regional tensions and the global "war on terror" narrative. Whereas the latter notion is equally shared by Protestants, they are more emphatic in their attempts to convert Muslims in all regions of Ethiopia, partially combined with a perspective of "spiritual warfare" in combating "the evil forces of Islam." From the Muslim side, the more fragile relationship towards Christians has produced intense debates about their position in the Ethiopian society and $v i s-\grave{a}$-vis the other religious groups. It has rekindled the image of being victimized, both in relation to the Orthodox understanding of Ethiopia as a "Christian Island", seen as continuation of past discriminatory sentiments, and in connection to the Protestant efforts in evangelizing them. ${ }^{\text {lix }}$

Leading to a more clear-cut demarcation of religiously marked boundaries this divide is aggravated through the production of polemic literature and audio-visual materials, through which both Muslims and Christians are forwarding negative images of the other. Books, VCDs, CDs and DVDs of this nature are made available for massconsumption, both as translations and as locally produced material.

\section{Conclusions}

In contrast to previous governments, the EPRDF has sought to accommodate the role of religion in the Ethiopian society. It has provided more space for the country's religions, separate from state and politics, and constitutionally enshrined religious equality and freedom of consciousness. However, the EPRDF has not fully succeeded in keeping religions and politics apart. As this paper has demonstrated, the ruling party has been carefully monitoring the space it has provided, and has on numerous occasions interfered in religious matters.

Increased religious activism and fragile inter-religious relations have spurred Protestants, Orthodox and Muslims to create their own, and largely competing narratives on the meaning of Ethiopia. Drawing upon Ethiopian historiography in a highly selective manner, each of these narratives has generated particular perceptions of the "other" and politics in general. For the EOC, the EPRDF take-over has entailed a severe realignment, 
from the reversal of the political co-optation under the Derg to the loss of previous political privileges. Increasingly challenged by the growth of Protestantism, the church has sought to transcend the idea of religious equality by reiterating its centrality for Ethiopian history and identity, a notion which is contested by Protestants and Muslims alike.

Protestants on the other hand, have largely profited from the new political climate, which for the first time awarded them official recognition on par with the other religious communities. Their growth, however, is nevertheless shaped and guided by actions of the executive, most of all in relation to registration and land leases. Therefore, the prominence of the persecution narrative among Protestants can be read as an implicit protest against potential government overreach.

Among Ethiopia's Muslim there is an increasing yearning for building unity, in which religion is gaining ground as point of identification. One question is whether this will supersede ethnic boundaries, and another question is how the Ethiopian government and the public will react to this development. The lack of a real democratization process, the continued marginalization of Muslim communities - coupled with regional tensions and global conflicts - could potentially radicalize Ethiopian Muslims and lead to the emergence of groups favouring stronger detachment from the wider society and forwarding a more exclusivist agenda.

The emergence of a pluralized religious factor in Ethiopian politics therefore is connected to vital questions of nationhood, identity and representations, which are likely to remain significant as Ethiopia re-appropriates its legacy. In this sense religion constitutes a significant force and is likely to remain relevant in the years to come.

\section{Notes}


i The authors contributed equally to the writing of this article.

${ }^{i i}$ Cf. Haustein, "Navigating Political Revolutions"; For more details on the situation for the shari' $a$ courts, see

"Proclamation to Establish Kadi Courts." Negarit Gazeta 1, no. 12 (1942); "Proclamation to Provide for the Establishment of Naiba and Kadis Councils", Negarit Gazeta 3, no. 62 (1944); Ibrahim, "Freedom of Religion"; Abdul "Sharia Courts in Ethiopia".

iii See Clapham, Transformation and Continuity, 156; Teferra, The Ethiopian Revolution, 274-284.

${ }^{\text {iv }}$ Meles Zenawi renounced Marxism-Leninism at about the same time as Mengistu Hailemariam, see Andargachew, The Ethiopian Revolution, 362.

vee Young, Peasant Revolution, 177.

${ }^{v i}$ Hussein, Islam and Islamic Discourse.

vii See Penal Code, $\S 476$; Criminal Code $\S 482$. Participation is fined with 500 or 1,000 Birr, respectively, leaders can be put into prison for up to six months or up to twelve months.

viii "Legal Notice No. 321 of 1966: Regulations Issued Pursuant to the Control of Associations Provision of the Civil Code of 1960." Negarit Gazeta 26, no.1 (1966):1-10), here $\S 8(1)$.

${ }^{\text {ix }}$ Traditional religions (2.7 percent), Catholicism ( 0.7 percent) and others $(0.6)$ percent form a small minority. These numbers have been criticized, most of all by the Muslim community. See e.g. "Ethiopia: Muslim Critics Reject National Census for "Missing Millions," Jimma Times, December 27, 2007. http://jimmatimes.com/article.cfm?articleID=31653. (accessed September 23, 2010)

${ }^{\mathrm{x}}$ Central Statistical Authority, The 1984 Population, 60.

${ }^{x i}$ Central Statistical Authority, The 1994 Population,129.

xii See Haustein, "Writing Religious History" for a comprehensive treatment.

xiii See ibid., 18-21.

xiv See Donham, Marxist Modern, 144.

${ }^{\mathrm{xv}}$ Cf. Eide, Revolution and Religion, 243-245; Gemechu, "A Church Under Challenge”, 128.

${ }^{\text {xi }}$ See Tsega, "Protestant Mission Activities"; U.S. Department of State, Ethiopia International Religious Freedom, for such occurrences in Bahir Dar (1994) and Mekele (2003).

${ }^{\text {xvii }}$ Cf. Haustein, "Navigating Political Revolutions", 124-130.

xviii See Gemechu, A Church Under Challenge, 137-142; Mitiku, "The Challenge of Language", 27-38. The breakaway faction initially was led by the former president of the EECMY, Francis Stephanos.

xix "Separated Mekane Yesus Churches declare their Unification." http://www.eecmy.org/?page=!news\&article=32 (accessed October 20, 2010)

${ }^{\mathrm{xx}}$ Cf. ibid.

${ }^{x x i}$ Cook, Observer's Report.

xxii See Abuna, The Ethiopian Tewahedo Church, 89-92.

xxiii The Coptic Church had never recognized the Derg-appointed patriarchs, arguing that unless Abuna Theophilos' death was confirmed, a new appointment would be uncanonical. The selection of a disciple of Theophilos and the ecclesial burial of Theophilos' remains one day before Paulos was installed also signify the attempt to restore canonicity and the recognition of the Coptic Church.

${ }^{\text {xxiv }}$ See Ethiopian Orthodox Church, Resolutions; Legitimate Holy Synod of the Ethiopian Orthodox Church, Letter of

Excommunication.

xxv See http://www.ethiopianreview.com.

${ }^{x x v i}$ Cf. "The 2005 Ethiopian Election Timeline." http://www.abbaymedia.com/2005_Ethiopian_Election_Timline.htm (accessed October 22, 2010).

xxvii See Ethiopian Human Rights Council, Illegal Detention. The monk wanted to hand a petition to the Patriarch, while Paulos' guards apparently believed that he wanted to assassinate him.

xxviii Hussein, "Islam and Islamic Discourse", 789f; Nuredin, "The Establishment of the Supreme Council".

xxix Østebø, “Localising Salafism”, 230.

${ }^{\mathrm{xxx}}$ Hussein, "Islamic Literature".

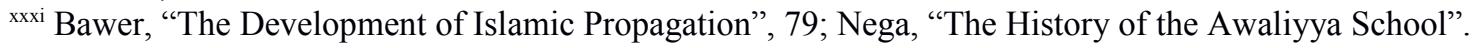

xxxii The incident seems to have been spurred by internal rivalry within the Addis Ababa Islamic Affairs Supreme Council.

See Abbink, “An Historical-Anthropological Approach", 118; Hussein, "Coexistence and/or Confrontation”, 17.

xxxiii This was according to reports in Addis Zemen, 27 June and 5 July (1995) and in Africa Confidential, 7 June (1995).

${ }^{\text {xxxiv }}$ For some examples of the public Ethiopian debate, see Hibret, "Proof of Wahabi"; Alem, "Saudi-Arabia's Wahabism"; Johannes, "The Emergence of Radical Islam".

${ }^{\mathrm{xxxv}}$ Barnes \& Hassan, "The Rise and Fall", 4.

xxxvi See Corazza, "State and Religion", 367.

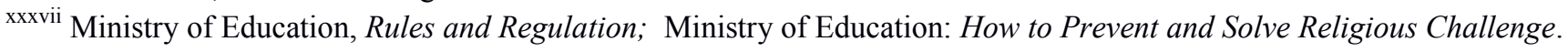


xxxviii The order was formally issued by EIASC (letter to the district Islamic Affairs Bureaus, 25 March 2009). The registration-form is available at http://blog.ethiopianmuslims.net/negashi/?p=353 (accessed 29 April 2010).

xxxix "Information on the decrees made by the Ethiopian Islamic Affairs Supreme Council", letter from EIASC, 23 February 2009.

${ }^{\mathrm{xl}}$ These have been posted on the website http://blog.ethiopianmuslims.net/negashi/ saying that the government in February/March 2009 planned to carry out a massive campaign against the Muslims.

xli General Secretariate, Ethiopia's Church, 7.

xlii The Mahibere Kidusan is an Orthodox youth movement that emerged from a number of university student groups looking to preserve their religious tradition during the Derg. It was officially accepted by the EOC Sunday School Department in May 1990. The Mahibere Kidusan supports and promotes various church activities among youths, and by strengthening youth identification with the Orthodox Church it seeks to protect the church from further incursions of Protestantism, and also from a perceived threat of Muslim fundamentalism. See Mahibere, Who is Mahibere Kidusan, ch 3. xliii Cf. Mengistu and Asamenu, Church History, 181-195.

xliv Ibid. 164-169.

xlv See also Esubalew, Gates of Hell.

xlvi See Bekele, Revival. Ethiopia, 115-150.

xlvii Ibid. 139.

xlviii See http://www.ethiopianmuslims.net/index.php?option=com_content\&view=article\&id=141 (accessed 10/21/2010)

xlix See http://www.ethiopianreview.com/content/8226 (accessed 10/21/2010)

${ }^{1}$ See Gemechu, A Church Under Challenge, 133-136.

li The Oromo Salafis have, on the other hand, been clearly supportive of the Oromo ethno-nationalist movement and the OLF, indicating that Salafism as a transnational movement has been unable to surpass ethnic boundaries. However, the internal frictions within OLF in recent years seem to have defused much of the ethno-nationalistic fervour among the Oromo and increased their disillusions.

lii Takfir wal Hijra first arrived in Ethiopia in 1992 from Sudan. It was soon denounced by the Salafi establishment and by Muslim scholars in general, causing its eventual decline. The word Takfir refers to the issue of declaring a fellow Muslim an apostate. The practical consequences in Ethiopia has been that followers of the Takfir wal Hijra refuse to pray with other Muslims in the mosques and organize their own celebrations of Muslim holidays.

liii Interview, Addis Ababa 20 February 2010.

${ }^{\text {liv }}$ Cf. Memher, Saint or Abyss; Sereqe, Prayer to the Dead.

Iv See Data, "Changing Youth Religiosity".

${ }^{\text {lvi }}$ For more details, see Østebø, "Localising Salafism", 263.

lvii Zelalem, "The 2006 Religious Conflict", 81.

lviii Medhane, Ethiopia: Religion.

${ }^{\text {lix }}$ Muslims were highly provoked by the extensive celebration of Timket (Epiphany) in 2010. They saw it as an explicit demonstration of Orthodox power, and viewed its semi-official character as a proof of the authorities' religious biases (Interview, Addis Ababa 16 February 2010).

\section{Bibliography}

Abdul Wasie Yusuf. "Sharia Courts in Ethiopia: Their Status, Organisation and Functions." BA-thesis in Law, Haile Sellassie I University, 1971.

Abbink, Jon. "An Historical-Anthropological Approach to Islam in Ethiopia: Issues of Identity and Politics." Journal of African Cultural Studies 11, no. 2 (1998): 109-24.

Abuna Yesehaq. The Ethiopian Tewahedo Church: An Integrally African Church. $3^{\text {rd }}$ ed. Nashville, TN: Winston-Derek Publishers, 2005.

Alem Zele-Alem. "Saudi Arabia's Whahabism and the Threat to Ethiopia's National Security." http://www.ethiomedia.com/press/wahabism threat to ethiopia.html (accessed 25 October, 2007). 
Andargachew Tiruneh. The Ethiopian Revolution 1974-1987: A Transformation from an Aristocratic to a Totalitarian Autocracy. Cambridge: Cambridge University Press, 1993.

Barnes, Cedric., and Harun Hassan. "The Rise and Fall of the Mogadishu's Islamic Courts." Chatham House Briefing Paper 7, no. 2 (2007)

Bawer Oumer. "The Development of Islamic Propagation (Da'wa) in Addis Ababa and its Surroundings." MA-thesis in History, Addis Ababa University, 2006

Bekele Woldekidan. Rìvayval: Ityop'ya 'ina yemech'ereshaw mech'eresha. (Revival. Ethiopia and the Final End) Addis Ababa: Addis Ababa Full Gospel Believers' Church, 2002.

Central Statistical Authority. The 1984 Population and Housing Census of Ethiopia: Analytical Report at National Level. Addis Ababa: Central Statistical Authority, 1991.

Central Statistical Authority. The 1994 Population and Housing Census of Ethiopia. Results at Country Level, vol. 1, Statistical Report. Addis Ababa: Central Statistical Authority, 1998.

Clapham, Christopher. Transformation and Continuity in Revolutionary Ethiopia. Cambridge: Cambridge University Press, 1988.

Cook, Ginni. "Observer's Report of the Ethiopian Orthodox Church 10th Parish Council General Assembly, Addis Ababa, 28-31 October 1991." Geneva: WCC Archives, Internal Report, 1991.

Corazza, Marta Torcini. "State and Religion in the Constitution and Politics of Ethiopia." European Journal for Church and State Research 9 (2002): 351-395.

Data Dea. "Changing Youth Religiosity in Ethiopia: A Generational Perspective." In Generations in Africa: Connections and Conflicts ed. by Erdmute Alber, Sjaak van der Geest, and Susan R. Whyte, 311-332. Münster: Lit, 2008.

Donham, Donald L. Marxist Modern: An Ethnographic History of the Ethiopian Revolution. Berkeley, CA: University of California Press, 1999.

Eide, Øyvind M. Revolution and Religion in Ethiopia: Growth and Persecution of the Mekane Yesus Church, 1974-85. $2^{\text {nd }}$ ed. Oxford: James Currey, 2000.

Esubalew Belete. Yegehanem dejoch. Protestantawī jehād be'ītyop'yawinet - tewahidonetsaysiffefem. (Gates of Hell. When the Protestant Jihad against Ethiopianess - Oneness - Thrives), Alexandria, VA: Artistic Printers, 2004.

Ethiopian Human Rights Council, "Illegal Detention.” Special Report 15, May 27, 1997, http://www.ethiopians.com/rep15.html (accessed January 29, 2011).

Ethiopian Orthodox Church. "Resolutions Passed by the Holy Synod of the Ethiopian Orthodox Tewahedo Church. February 2, 2007." http://www.eotc-patriarch.org/Resolutions\%20passed\%20by $\% 20$ the $\% 20$ Holy $\% 20$ Synod $\% 20$ of $\% 20$ the $\% 20$ Ethiopian $\% 20$ Orthodox $\% 20$ Tewahedo $\% 20$ Church.pdf (accessed October 18, 2010) 
Gemechu Olana. 'A Church under Challenge: The Socio-Economic and Political Involvement of the Ethiopian Evangelical Church Mekane Yesus (EECMY).' Berlin: research dissertation, 2006.

General Secretariat of the Patriarchate of the Ethiopian Orthodox Tewahedo Church. Ye'îtyop'ya bēte kristīyan tinantinana zārēe. (Ethiopia's Church Yesterday and Today) Addis Ababa: Commercial Printing Press, 1997.

Ibrahim Idris. "Freedom of Religion and Secularization of the State: The Legal Status of Islamic Law and Shariat Courts in Ethiopia." In Proceedings of the 12th International Conference of Ethiopian Studies, Michigan, 1994, ed. By H.G. Marcus, vol. 2, 151-156. Lawrensville, NJ: Red Sea Press.

Haustein, Jörg "Navigating Political Revolutions: Ethiopia's Churches During and After the Mengistu Regime." In Falling Walls: The Year 1989/90 as a Turning Point in the History of World Christianity ed. by Klaus Koschorke, 117-136. Wiesbaden: Harrassowitz, 2009.

Haustein, Jörg. "Writing Religious History. The Historiography of Ethiopian Pentecostalism." Dr. theol. thesis., University of Heidelberg, 2009.

Hibret Selamu. "Proof of Wahabi Activities in Ethiopia." www.ethiomedia.com/newspress/proof_of_whahabism_in_ethiopia (accessed 12 October, 2007).

Hussein Ahmed. "Coexistence and/or Confrontation: Towards a Reappraisal of ChristianMuslim Encounters in Contemporary Ethiopia.” Journal of Religion in Africa 36, no. 1 (2006): 4-22.

Hussein Ahmed. "Islam and Islamic Discourse in Ethiopia (1973-1993)." In Proceedings of the 12th International Conference of Ethiopian Studies, Michigan, 1994, ed. H.G. Marcus, vol 1, 775-801. Lawrensville, NJ: Red Sea Press.

Hussein Ahmed. "Islamic Literature and Religious Revival in Ethiopia (1991-1994)." Islam et Sociétés au Sud du Sahara 12 (1998): 89-108.

Johannes Sebhatu. "The Emergence of Radical Islam in Ethiopia (1991-2004)." www.ethiomedia.com/commentary/radical_islam_in_ethiopia (accessed 25 September, 2007).

Legitimate Holy Synod of the Ethiopian Orthodox Church. "Letter of Excommunication from 30 Tir 1999". Available online http://www.st-gebriel.org/holysynod/eotc excommunication.pdf (accessed October 19, 2010)

Mahibere Kidusan. "Māhābere k'idusān mān new? Kifil sost" (Who is Mahibere Kidusan? Chapter 3). http://www.eotcmk.org/site/index.php?option=com content\&task=view\&id=50\&Itemid=2 (accessed October 29, 2010)

Medhane Tadesse. "Ethiopia: Religion - a New Breeding Ground for Conflict." http://www.irinnews.org/Report.aspx?ReportId=43642 (accessed 15 February, 2008).

Memher Getachew. Gedil weys gedel? (Saint or Abyss?) Addis Ababa, 2003. 
Mengistu Gobeze and Asamenu Kasa. Yebēte kristīyan tarīk: K'ut'r 2. (Church History. Vol. 2) Addis Ababa: Mahibere Kidusan, 2008.

Ministry of Education, Ethiopia. Rules and Regulations on Religious Practices in Educational Institutions (Ministry of Education: Addis Ababa, May 2007).

Ministry of Education: How to Prevent and Solve Religious Challenges that Occur in Educational Institutions (Ministry of Education, Addis Ababa, November 2007.

Mitiku Tesfa. "The Challenge of Language for the EECMY.” B.Th. thesis, Mekane Yesus Seminary, Addis Ababa, 1999.

Nega Aba Jebel. "The History of the Awaliyya School 1961-1986." BA-thesis in History, Addis Ababa University, 1986.

Nuredin Jemal. "The Establishment of the Supreme Council: Development, Strength and Weaknesses.” Issued by The Ethiopian Islamic Affairs Supreme Council, Addis Ababa, 1998.

Østebø, Terje. "Localising Salafism: Religious Change among Oromo Muslims in Bale, Ethiopia.” Ph.D.-thesis, Stockholm University, 2008.

Sereqe Berhan Sewongel. Ts'elot zemutān: Mutān selemutān sīts'eliyu. (Prayer to the Dead: When the Dead Pray for the Dead.) Addis Ababa, 2004.

Teferra Haile-Selassie. The Ethiopian Revolution 1974-1991: From a Monarchical Autocracy to a Military Oligarchy. London: Kegan Paul International, 1997.

Tsega Endalew. "Protestant Mission Activities and Persecutions in Bahər Dar, 1968-1994: A Chronicle.” In Ethiopia and the Missions: Historical and Anthropological Insights ed. by Verena Böll et al., 209-220. Münster: Lit, 2005.

U.S. Department of State, Bureau of Democracy, Human Rights and Labor. "Ethiopia. International Religious Freedom Report 2003.” http://www.state.gov/g/drl/rls/irf/2003/23705.htm (accessed January 10, 2009)

Young, John. Peasant Revolution in Ethiopia: The Tigray People's Liberation Front, 1975 1991. Cambridge: Cambridge University Press, 1997.

Zelalem Temesgen. "The 2006 Religious Conflict in Didessa and Gomma Waradas of Western Oromia.” Master's thesis in Ethiopian Studies, Addis Ababa University, 2010. 